\title{
Chemical Pesticides and Plant Essential Oils for Disease Control of Tomato Bacterial Wilt
}

\author{
Young Hee Lee', Chang Won Choi ${ }^{2}$, Seong Hwan Kim ${ }^{3}$, Jae Gill Yun${ }^{1}$, Seog Won Chang ${ }^{4}$, Young Shik Kim ${ }^{5}$ \\ and Jeum Kyu Hong ${ }^{1 *}$ \\ ${ }^{1}$ Department of Horticultural Sciences, Gyeongnam National University of Science and Technology (GNTech), Gyeongnam 660- \\ 758, Korea \\ ${ }^{2}$ Department of Biology and Medicinal Science, Paichai University, Daejeon 302-735, Korea \\ ${ }^{3}$ Department of Microbiology and Institute of Basic Sciences, Dankook University, Chungnam 330-714, Korea \\ ${ }^{4}$ Korea Golf University, Gangwon 225-701, Korea \\ ${ }^{5}$ Department of Plant Science and Technology, Sangmyung University, Choongnam 330-720, Korea
}

(Received on October 25, 2011; Revised on December 6, 2011; Accepted on December 24, 2011)

Efficacy of different control methods was evaluated for disease management of tomato bacterial wilt caused by Ralstonia solanacearum. All six chemical pesticides applied to the bacterial suspension showed in vitro bactericidal activities against $\boldsymbol{R}$. solanacearum. Minimal inhibitory concentrations (MICs) of copper hydroxide (CH), copper hydroxide-oxadixyl mixture $(\mathrm{CH}+\mathrm{O})$, and copper oxychloride-dithianon mixture $(\mathrm{CO}+\mathrm{D})$ were all $200 \mu \mathrm{g} / \mathrm{ml}$; MIC of copper oxychloride-kasugamycin (CO+K) mixture was $100 \mu \mathrm{g} / \mathrm{ml}$; MICs of both streptomycin-validamycin $(\mathrm{S}+\mathrm{V})$ and oxine copper-polyoxine $B$ mixture $(\mathrm{OC}+\mathrm{PB})$ were $10 \mu \mathrm{g} / \mathrm{ml}$. Among these chemical pesticides, treatment of the detached tomato leaves with the 5 pesticides $(1 \mathrm{mg} / \mathrm{ml})$, except for $\mathrm{OC}+\mathrm{PB}$ delayed early wilting symptom development caused by the bacterial inoculation $\left(10^{6}\right.$ and $\left.10^{7} \mathrm{cfu} / \mathrm{ml}\right)$. Four pesticides, $\mathrm{CH}, \mathrm{CH}+\mathrm{O}, \mathrm{CO}+\mathrm{K}$ and $\mathrm{S}+\mathrm{V}$, showed disease protection in pot analyses. Six plant essential oils, such as cinnamon oil, citral, clove oil, eugenol, geraniol and limonene, differentially showed their antibacterial activities in vitro against $R$. solanacearum demonstrated by paper disc assay. Among those, cinnamon oil and clove oil exert the most effective activity for protection from the wilt disease caused by the bacterial infection $\left(10^{6} \mathrm{cfu} / \mathrm{ml}\right)$. Treatment with cinnamon oil and clove oil also suppressed bacterial disease by a higher inoculum concentration $\left(10^{7} \mathrm{cfu} / \mathrm{ml}\right)$. Clove oil could be used for prevention of bacterial wilt disease of tomato plants without any phytotoxicity. Thus, we suggest that copper compounds, antibiotics and essential oils have potency as a controlling agent of tomato bacterial wilt.

Keywords : chemical pesticide, essential oil, tomato bacterial wilt

\footnotetext{
*Corresponding author.

Phone) +82-55-751-3251, FAX) +82-55-751-3257

E-mail)jkhong@gntech.ac.kr
}

Bacterial spot and bacterial wilt diseases of tomato and pepper plants, caused by Xanthomonas campestris pv. vesicatoria and Ralstonia solanacearum, are economically devastating in yield production worldwide (Hayward, 1991; Jones et al., 1998). Recently, reports on new strains of the two bacterial species have been increasing in tomato and pepper fields of many different countries including Turkey, Egypt and Italy (Adb-Alla and Bashandy, 2008; Aysan and Sahin, 2003; Loreti et al., 2008). R. solanacearum is an A2 quarantine pest for EPPO (European and Mediterranean Plant Protection Organization) and for the European Union, particularly regarding its race 3 (biovar 2) which causes brown rot of potato and bacterial wilt of tomato. It is thought to survive in soil for several years and infect host plants through root tissues (Graham and Lloyd, 1979; van Elsas et al., 2000). In addition, the high incidence of the disease in the field indicates that many factors involve the survival of the bacterium. Temperature is one of the most important factors affecting bacterial survival in soils (Hayward, 1991), and temperature fluctuations are involved in viability of $R$. solanacearum race 3 , biovar 2 , in infected geranium, potato and tomato plants (Scherf et al., 2010).

Various methods including bactericide treatment have been applied for the bacterial disease control in tomato plant fields. Two antibiotics, streptomycin and oxytetracyclin were effective to protect tomato fruits against bacterial speck disease by Pseudomonas syringae pv. tomato (Jardine and Stephens, 1987). Efficacy of copper-related chemicals has been verified for control of bacterial speck and bacterial spot diseases (Conlin and McCarter, 1983; Saad and Abul Hassan, 2000). However, occurrence of antibiotic- and copper-resistant strains of $P$. syringae pv. tomato and $X$. campestris pv. vesicatoria have been reported (Adaskaveg and Hine, 1985; Cuppels and Elmhirst, 1999; Ritchie and Dittapongpitch, 1991). In South Korea, five strains were re- 
sistant to copper sulfate and one was resistant to streptomycin among 66 strains of $X$. campestris pv. vesicatoria isolated from pepper fields 1993-1994 (Lee and Cho, 1996). These prompted the search for alternatives for bacterial disease control such as application of antimicrobial plant extracts and defense activator (Louwes et al., 2001; Romero et al., 2001; Seo et al., 2004). Although diverse applications have been tried to control bacterial spot and speck diseases, a few studies were conducted to figure out appropriate control methods of bacterial wilt disease of tomato plants. Some fumigants, including chloropicrin, were effective for controlling bacterial wilt of tomato (Enfinger et al., 1979).

Antimicrobial essential oils, such as thymol, palmarosa oil originated from plant materials have been suggested as one of the promising eco-friendly alternatives of chemical pesticides (Ji et al., 2005; Pradhanang et al., 2003). Use of genetically engineered Hrp mutants of $R$. solanacearum and antagonistic bacteria were also suggested for biological control of tomato bacterial wilt (Frey et al., 1994; Park et al., 2007b; Suk et al., 2006). Enhanced disease resistance of tomato plants to bacterial wilt disease was accomplished by treatment with defense activators, acibenzolar- $S$-methyl (Pradhanang et al., 2005). More recently, riboflavin (vitamin B2) has been recognized as a plant defense activator in tobacco plants against $R$. solanacearum infection (Liu et al., 2010). However, more efficient control methods for tomato bacterial wilt are being evaluated in integrated pest management.

Fourteen pesticides were approved for bacterial spot control, and only one pesticide, dazomet, was for bacterial wilt of pepper plants in South Korea in 2010. However, no appropriate pesticide has been suggested for bacterial disease management of tomato production, and economic loss has been drastically increased because of occurrence of bacterial wilt in tomato fields. In this study, we are aiming to investigate antibacterial activity of commercialized chemicals in vitro and in greenhouse for the major bacterial disease control in tomato plants. Application of essential oils and plant defense activators to tomato plants was also evaluated for bacterial wilt control for eco-friendly tomato production.

\section{Materials and Methods}

Plant and bacteria growth conditions. Tomato (cv. Cupirang) was sown in commercial soil mixture in pot (80 $\mathrm{mm}$ in diameter), and grown in a plant growth room, in which temperatures ranged from $19-21^{\circ} \mathrm{C}$ at night and $26-$ $28^{\circ} \mathrm{C}$ during the day. Five-week-old tomato plants were used for bacterial inoculation. $R$. solanacearum strain GMI1000 was cultured in CPG media (Schaad et al., 2001) supplemented with $0.05 \%$ (w/v) 2,3,5-triphenyltetrazolium
Table 1. Minimum inhibitory concentrations (MICs) of different chemical pesticides against Ralstonia solanacearum, as determined by the microtiter broth dilution method

\begin{tabular}{lcc}
\hline \hline \multicolumn{1}{c}{ Pesticides } & Type & $\begin{array}{c}\text { MICs } \\
(\mu \mathrm{g} / \mathrm{ml})\end{array}$ \\
\hline Copper hydroxide (CH) & WG & 200 \\
Copper hydroxide + Oxadixyl (CH+O) & WP & 200 \\
Copper oxychloride + Dithianon (CO+D) & WP & 200 \\
Copper oxychloride + Kasugamycin (CO+K) & WP & 100 \\
Streptomycin + Validamycin A (S+V) & WP & 10 \\
Oxine copper + Polyoxin B (OC+PB) & WP & 10 \\
\hline
\end{tabular}

WG, wettable granule; WP, wettable powder

chloride (TZC) (Kelman, 1954) at $30^{\circ} \mathrm{C}$ overnight. Bacterial suspension was adjusted at $\mathrm{OD}_{600}=0.15$ with a population of $10^{8} \mathrm{cfu} / \mathrm{ml}$ in sterile water. Bacterial suspension at the concentrations of $10^{5} \mathrm{cfu} / \mathrm{ml}$ was used for in vitro antibacterial activity using well plates. Relatively high concentrations of $10^{6}-10^{8} \mathrm{cfu} / \mathrm{ml}$ were inoculated to detached tomato leaves or seedlings.

In vitro antibacterial activity of chemicals. Six pesticides summarized in Table 1 were commercial formulations approved for bacterial spot disease (X. campestris pv. vesicatoria) during pepper production in South Korea. Among them, copper hydroxide and copper hydroxide-oxadixyl, are also registered as pesticides for early blight (Alternaria solani) and Phytophthora blight (Phytophthora infestans, $P$. capsici) of tomato plants, respectively. Minimum inhibitory concentrations (MICs) of each pesticide against $R$. solanacearum were determined in 24-well microtiter dishes. The aliquot $(50 \mu \mathrm{l})$ of bacterial suspension $\left(10^{5} \mathrm{cfu} / \mathrm{ml}\right)$ of $R$. solanacearum strain GMI1000 was added to the well plates containing increasing concentrations of different pesticides in the liquid media. The bacteria were cultured 2-3 days to evaluate bactericidal efficacy. The lowest concentrations of each pesticide where no bacterial growth was observed were considered to be MICs.

Direct antibacterial activities of essential oils were determined by paper disc diffusion assay (Bajpai et al., 2010). A $100 \mu \mathrm{l}$ of the bacterial suspension $\left(10^{7} \mathrm{cfu} / \mathrm{ml}\right)$ of $R$. solanacearum was evenly spread onto nutrient agar media. Sterile filter paper discs ( $8 \mathrm{~mm}$ in diameter) were soaked with different amount of essential oils $(2,5$ and $10 \mu \mathrm{l} /$ disc $)$ prepared in ethanol, or soaked in ethanol as a control. The discs were allowed to dry and to vaporize the ethanol for 15 min at room temperature, and transferred onto the nutrient agar media containing $R$. solanacearum. The plates were incubated upside down at $30^{\circ} \mathrm{C}$ for 4 days. Antibacterial activity was evaluated by measuring the diameter of the cleared inhibition zone. All experiments were repeated 4 times. 
Disease protection activity of pesticides and essential oils using detached tomato leaves. Different concentrations of pesticides and essential oils were applied to the $10 \mathrm{ml}$ of bacterial suspension $\left(10^{6}\right.$ or $\left.10^{7} \mathrm{cfu} / \mathrm{ml}\right)$ of $R$. solanacearum in $50 \mathrm{ml}$-conical tubes. Third leaves of the 5-week-old tomato plants were removed and weighed just before inoculation. Petioles were immersed into the solution containing bacteria and/or candidate protection chemicals. For effect of essential oils on bacterial wilt of detached leaves, essential oils were applied to the bacterial suspension instead of pesticides. Fresh weight (FW) of the detached leaves was measured daily during wilting symptom development. Relative FW was calculated compared to those before bacterial inoculation, and was expressed for antibacterial efficacy of the pesticides and essential oils.

In planta antibacterial activity of pesticides and essential oils using tomato seedlings in pots. Twenty $\mathrm{ml}$ of pesticide or essential oil solutions were each poured evenly into a pot with one 5-week-old tomato seedling. The same volume of the bacterial suspension $\left(10^{8} \mathrm{cfu} / \mathrm{ml}\right)$ of $R$. solanacearum was also poured into the pot (Park et al., 2007a) to make a bacterial concentration of $10^{7} \mathrm{cfu} / \mathrm{ml}$ in pot. Disease progress with wilting symptom was monitored daily for 10 days and rated based on the method of Roberts et al. (1988): 0, healthy; 1, 1 to 25\% leaf area wilted; 2, 26 to $50 \%$ leaf are wilted; 3, 51 to $75 \%$ leaf area wilted; and 4, $>75 \%$ leaf area wilted. Area under the disease progress curve (AUDPC) was calculated as AUDPC $=\sum\left[\left(\mathrm{R}_{i+1}+\mathrm{R}_{i}\right) /\right.$ $2]\left[\mathrm{t}_{i+1}-\mathrm{t}_{i}\right]$, where $\mathrm{R}=$ disease rating at the $i$ th observation $\mathrm{t}_{i}$ $=$ time (days) since previous ratings at the $i$ th observation, and $n=$ total number of observations. Relative AUDPC $(\%)$ was obtained for pesticide-treated plant by comparison with the AUDPC data of the non-treated plant as $100 \%$.

Statistical analyses. Analysis of variance (ANOVA) was used to determine the effects of treatments on tomato leaf FW and AUDPC by tomato bacterial wilt symptom. Means were compared using Duncan's multiple range tests. Statistical analysis was performed with the SAS version 8.1 (SAS Institute, Inc., Cary. NC).

\section{Results}

In vitro effect of pesticides on $\boldsymbol{R}$. solanacearum growth. In vitro antibacterial activities were tested by determination of MICs in the micro well plates (Table 1). Six pesticides demonstrated different MICs against $R$. solanacearum strain GMI1000 in vitro. MICs of copper hydroxide $(\mathrm{CH})$, copper hydroxide-oxadixyl mixture $(\mathrm{CH}+\mathrm{O})$ and copper oxychloride-dithianon mixture $(\mathrm{CO}+\mathrm{D})$ were relatively higher at $200 \mu \mathrm{g} / \mathrm{ml}$, and MICs of copper oxychloride- kasugamycin $(\mathrm{CO}+\mathrm{K})$ mixture was $100 \mu \mathrm{g} / \mathrm{ml}$. By contrast, low MICs of streptomycin-validamycin $(\mathrm{S}+\mathrm{V})$ and oxine copper-polyoxin $\mathrm{B}(\mathrm{OC}+\mathrm{PB})$ mixtures were measured at 10 $\mu \mathrm{g} / \mathrm{ml}$.

In planta disease protection of pesticides on tomato bacterial wilt. In planta efficacy of each pesticide was evaluated using detached tomato leaves and reduced FW of the leaves caused by bacterial infection were measured (Fig. 1). Equal concentrations $(1 \mathrm{mg} / \mathrm{ml})$ of the six pesticides included in the bacterial suspensions $\left(10^{6} \mathrm{cfu} / \mathrm{ml}\right)$ were effective to reduce wilting symptom and loss of FW caused by bacterial infection. Tomato leaves with no pesticide were withered 2 days post-inoculation (dpi), and thereafter wilting became more severe, resulting in ca. $40 \%$ decline in FW at 5 dpi. Relative FW of pesticide-treated tomato leaves was higher than that of pesticide-untreated control leaves (Fig. 1A, 1B). All six pesticides significantly protected tomato leaves against bacterial wilt disease by a relatively low inoculation dose. However, OC+PB did not efficiently reduce bacterial disease caused by a higher inoculation dose $\left(10^{7} \mathrm{cfu} / \mathrm{ml}\right)$ in 3-5 dpi (Fig. 1C).

In planta efficacy of each pesticide was also investigated using tomato seedlings of 6-leaf stage (Fig. 2). Soil-drench

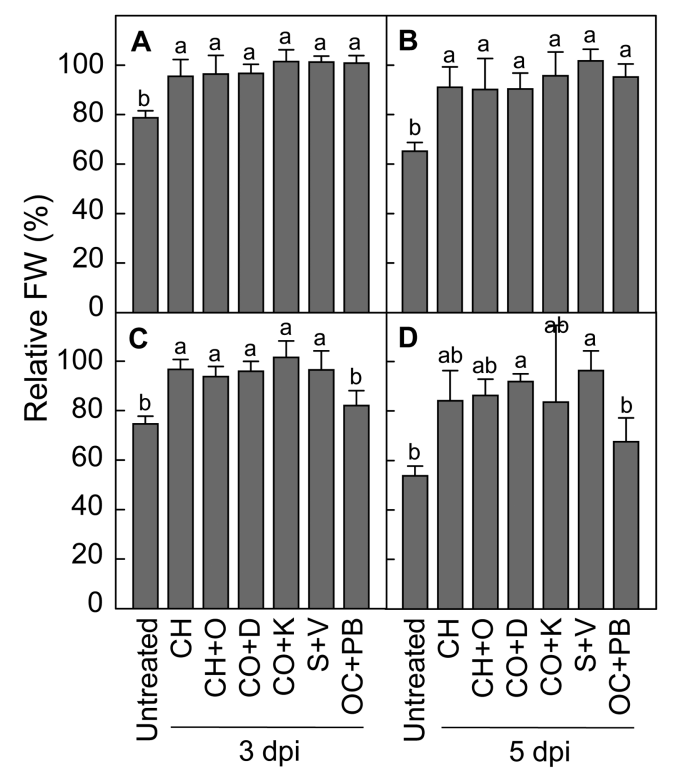

Fig. 1. Effect of pesticides on tomato bacterial wilt disease. Relative fresh weight of detached tomato leaves by petioleinoculated with $R$. solanacearum strain GMI1000 for 3 and 5 days. Disease protection by pesticide treatment against tomato bacterial wilt was presented as relative FW (\%) of treated leaves compared with that of the untreated leaves. (A and B) One mg/ml of pesticides and $10^{6} \mathrm{cfu} / \mathrm{ml}$ of bacterial suspension, (C and D) One $\mathrm{mg} / \mathrm{ml}$ of pesticides and $10^{7} \mathrm{cfu} / \mathrm{ml}$ of bacterial suspension. Mean separation by Duncan's multiple range test at $P=0.05$. The same letter above bars represented no significant difference between treatments. 


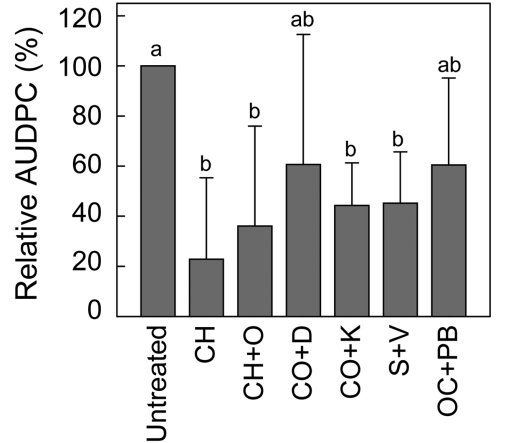

Fig. 2. Effect of pesticides on tomato bacterial wilt disease. Relative area under disease progress curve (AUDPC) used to evaluate bacterial disease caused by $R$. solanacearum strain GMI1000 for 10 days after soil-drench inoculation. Values presented are means and standard errors from four independent experiments. Mean separation by Duncan's multiple range test at $P=0.05$. The same letter above bars represented no significant difference between treatments.

inoculation of tomato seedlings resulted in gradual increase of disease severity with wilting symptom within 10 days. Minute wilting in 6-leaf stage of tomato plants first appeared $5 \mathrm{dpi}$, and then slightly increased to disease severity 1-2 2 days later. At $8-10 \mathrm{dpi}$, the tomato plants severely withered and died. Different pesticides were applied by soil-drench just before bacterial inoculation, and symptom development of pesticide-treated tomato plants were examined for 10 days. Disease progresses in pesticide-treated tomato plants were compared to those in the untreated plants, and demonstrated as relative AUDPC. $\mathrm{CH}, \mathrm{CH}+\mathrm{O}$, $\mathrm{CO}+\mathrm{K}$ and $\mathrm{S}+\mathrm{V}$ applications showed disease protection against bacterial wilt (Fig. 2).

In vitro effect of essential oils on $R$. solanacearum growth. In vitro bacterial growth of $R$. solanacearum was significantly affected by essential oil treatments, except for limonene as compared to the untreated control during incubation period (Table 2). More than $2 \mu \mathrm{l}$ of cinnamon oil, citral, clove oil, eugenol and geraniol showed drastic antibacterial activities in vitro. Two $\mu 1$ of cinnamon oil resulted in production of a cleared zone $41.74 \mathrm{~mm}$ in diameter, and treatment with 5 and $10 \mu \mathrm{l}$ increased the size
A

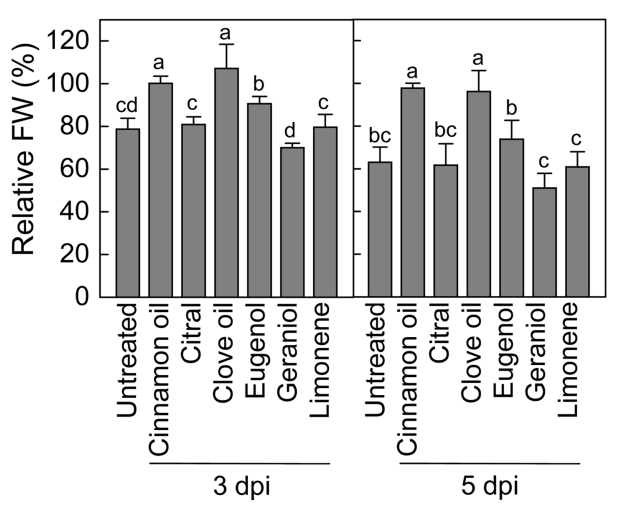

B

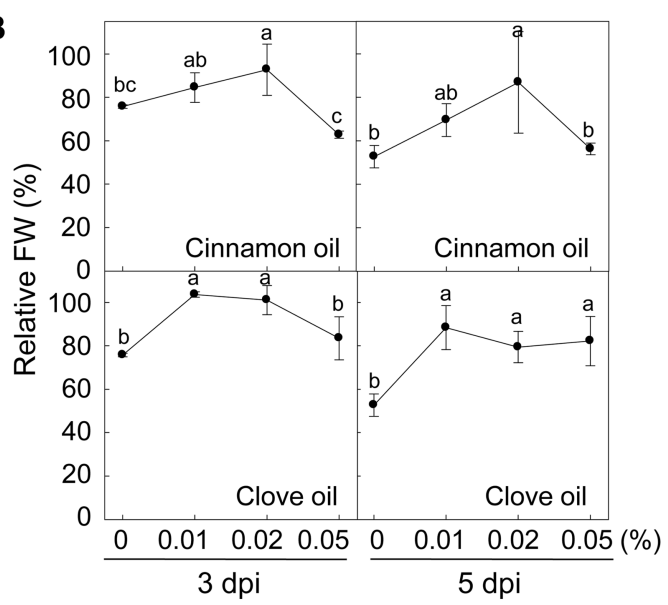

Fig. 3. Effect of essential oils on tomato bacterial wilt disease. (A) Relative FW of detached tomato leaves by petiole-inoculated with $R$. solanacearum GMI1000 $\left(10^{6} \mathrm{cfu} / \mathrm{ml}\right)$ for 3 and 5 days. Protection by $0.01 \%$ of each essential oil treatment against tomato bacterial wilt was presented as relative $\mathrm{FW}(\%)$ of treated leaves compared with that of the untreated leaves. (B) Effect of cinnamon oil and clove oil on disease protection against bacterial wilt caused by high inoculum concentration $\left(10^{7} \mathrm{cfu} / \mathrm{ml}\right)$. Mean separation by Duncan's multiple range test at $P=0.05$. The same letter above bars represented no significant difference between treatments.

of the cleared zone to 53.00 and $56.50 \mathrm{~mm}$, respectively. However, dose increase of cinnamon oil to $10 \mu \mathrm{l}$ did not enlarge the cleared zone significantly. Application of citral, clove oil, eugenol and geraniol also revealed their antibacterial activities with $2 \mu \mathrm{l}$ in disc, but the effects were not

Table 2. In vitro inhibitory activity of various essential oils against Ralstonia solanacearum strain GMI1000 (Rs-GMI1000) shown by diameter of inhibition zone $(\mathrm{mm})$

\begin{tabular}{cccccccc}
\hline \hline Bacteria & Dose $(\mu \mathrm{l}) /$ disc & Cinnamon oil & Citral & Clove oil & Eugenol & Geraniol & Limonene \\
\hline Rs-GMI1000 & 0 & 0.00 & 0.00 & 0.00 & 0.00 & 0.00 & 0.00 \\
& 2 & 41.74 & 7.50 & 11.50 & 16.75 & 7.25 & 0.00 \\
& 5 & 53.00 & 10.00 & 25.00 & 26.75 & 14.25 & 0.00 \\
& 10 & 56.50 & 14.50 & 34.00 & 28.00 & 22.25 & 0.00 \\
& LSD $_{0.05}$ & 5.02 & 1.00 & 2.28 & 5.70 & 2.97 & $\mathrm{~ns}$ \\
\hline
\end{tabular}


dramatic compared to that of cinnamon oil. Increasing concentrations of citral, clove oil, eugenol and geraniol led to augmentation of antibacterial activities. By contrast, limonene of 2-10 $\mu \mathrm{l}$ did not reveal any antibacterial activity.

In planta disease protection of essential oils on tomato bacterial wilt. In planta disease suppression efficacy of each essential oil was evaluated using detached tomato leaves (Fig. 3). Effect of essential oils for disease suppression was investigated using $10^{6} \mathrm{cfu} / \mathrm{ml}$ of the bacterial suspension (Fig. 3A). Cinnamon oil, clove oil and eugenol treatment $(0.01 \%)$ significantly decreased bacterial disease development demonstrated by FW loss at 3 dpi with $R$. solanacearum. Both cinnamon oil and clove oil still showed disease protection effect against tomato bacterial wilt at 5 dpi, however, other essential oils did not render disease protection. Two essential oils, cinnamon oil and clove oil were also evaluated in the light of disease suppression against high dose of inoculum density $\left(10^{7} \mathrm{cfu} / \mathrm{ml}\right)$ (Fig. 3B). Cinnamon oil of $0.02 \%$ showed increased FW compared to that of untreated tomato leaves in 3-5 dpi with phytotoxic effect on tomato petioles. Higher concentration of cinnamon oil $(0.05 \%)$ resulted severe tissue damage without bacterial inoculation (data not shown). Clove oil treatment of $0.01-0.02 \%$ increased FW compared to that of untreated control at $3 \mathrm{dpi}$. Disease suppression effect prolonged to 5 dpi.

Disease suppression by clove oil treatment was also found in the intact tomato seedlings in pots infested by $R$. solanacearum (Fig. 4). Although R. solanacearum-infected tomato plants without application of clove oil were severely wilted at $7 \mathrm{dpi}, 0.005-0.01 \%$ of clove oil treatment significantly decreased tomato bacterial wilt (Fig. 4A), demonstrated by reduced relative AUDPC (Fig. 4B).
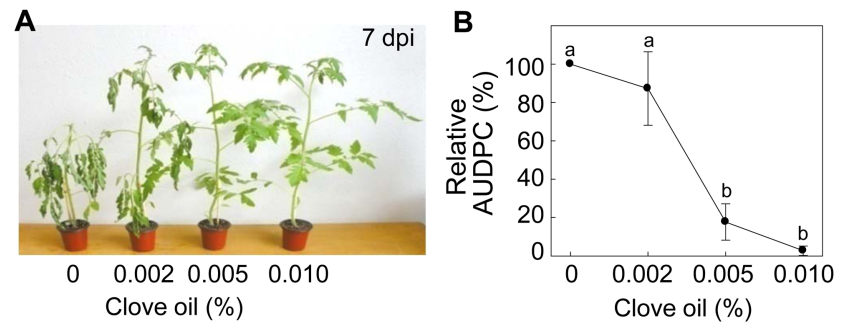

Fig. 4. Effect of clove oil on tomato bacterial wilt disease. (A) Disease symptoms of tomato plants in pots soil-drenched with the bacterial suspension with or without clove oil application. Photo was taken 7 days after bacterial inoculation. (B) Relative area under disease progress curve (AUDPC) used to evaluate bacterial disease caused by $R$. solanacearum strain GMI1000 for 10 days after soil-drench inoculation. Values presented are means and standard errors from four independent experiments. Mean separation by Duncan's multiple range test at $P=0.05$. The same letter above bars represented no significant difference between treatments.

\section{Discussion}

Although bacterial wilt of tomato is a devastating disease worldwide and yield loss are increasing, a proper disease control method could not be suggested so far. For disease control of bacterial wilt, planting resistance cultivars were screened and suggested. A few tomato cultivars had $R$. solanacearum resistance in recent studies (Carmeille et al., 2006; Han et al., 2009; Nakaho et al., 2004). However, changing resistant cultivars can sometimes lead to undesirable tomato traits. In this study, we investigated the effective disease management of tomato bacterial wilt by treatment with pesticides and plant essential oils. To this aim, in vitro antibacterial activities were investigated against $R$. solanacearum, causing tomato bacterial wilt. Additionally, detached petiole-inoculation method was applied for rapid, convenient and reliable disease evaluation, and disease protection was also evaluated in the intact tomato seedlings in pots.

Cultural practices, such as planting resistant cultivars, incorporation of plant growth-promoting rhizobacteria and composts, inducing plant disease resistance, are eco-friendly disease control methods for tomato bacterial wilt (Guo et al., 2004; Islam and Toyota, 2004; Pradhanang et al., 2005). Nevertheless, chemical control methods are still needed to cope with unexpected and drastic disease occurrence. Several decades ago, a few general-purpose soil fumigants such as chloropicrin were applied to eliminate $R$. solanacearum in tomato-growing fields (Enfinger et al., 1979). Validamycin A had antibacterial activity in vitro against $R$. solanacearum and efficiently delayed tomato bacterial wilt in greenhouse (Ishikawa et al., 1996). However, not so many antibacterial substances were examined for tomato disease control of bacterial wilt. Several chemical pesticides allowed for disease control of bacterial spot in pepper plants were selected to test whether or not these pesticides also have antibacterial activities against $R$. solanacearum. These are $\mathrm{CH}, \mathrm{CH}+\mathrm{O}$ mixture, $\mathrm{CO}+\mathrm{D}$ mixture, $\mathrm{CO}+\mathrm{K}$ mixture, $\mathrm{S}+\mathrm{V}$ mixture, $\mathrm{OC}+\mathrm{PB}$ mixture. Five of them are copper-related compounds, and three of them are antibioticcontaining materials. $\mathrm{CH}$ and $\mathrm{CH}+\mathrm{O}$ mixture are allowed to be used in tomato plants for early blight and Phytophthora blight, respectively, in South Korea. $\mathrm{CH}$ is registered for eco-friendly control to early blight of tomato in South Korea. But $\mathrm{CH}+\mathrm{O}$ mixture could be used for bacterial wilt control in tomato fields after registration test. Pesticides containing copper-related compounds are showing relatively higher MICs than those of antibiotics in our study. Copper and/or antibiotic compounds were suggested for the control of bacterial spot and speck diseases of tomato. However, copper and antibiotic-resistant strains were detected in pepper producing fields (Adaskaveg and Hine, 1985; 
Marco and Stall, 1983; Ritchie and Dittapongpitch, 1991), indicating that continuous use of the chemicals in tomato fields should be reconsidered. No disease control activities of these compounds against tomato bacterial wilt have been detected so far. Although occurrence of pesticide resistant strains of $R$. solanacearum causes worry, four pesticides, $\mathrm{CH}, \mathrm{CH}+\mathrm{O}, \mathrm{CO}+\mathrm{K}$, and $\mathrm{S}+\mathrm{V}$, verified in the present study, can be carefully considered for the integrated disease management of tomato bacterial wilt.

A variety of plant extracts were applied to reduce plant diseases in many crop productions (Ahmed et al., 2010; Choi et al., 2008; Muthukumar et al., 2010). In recent years plant essential oils have been known as one of the promising plant disease control agents in light of eco-friendly disease control using natural products (Isman, 2000). Essential oils extracted from palmarosa, lemongrass and eucalyptus plants have shown their direct antibacterial effects on $R$. solanacearum race 4 in vitro, and reduced bacterial wilt disease of edible ginger (Paret et al., 2010). Essential oils were also suggested for the control of several tomato diseases, late blight and grey mould (Soylu et al., 2006, Soylu et al., 2010). These reports suggest that treatment of tomato plants with different essential oils from diverse plant origins may be the way to find proper disease control methods for bacterial wilt. In tomato fields, soil treatment with both thymol and palmarosa oil reduced bacterial wilt disease as biofimugants (Ji et al., 2005). Untreated control tomato fields are highly infested by the bacterial wilt and $92.5 \%$ of the tomato plants were damaged in the fall of 2002, while thymol and palmarosa soil resulted in decreased disease incidence to 33.1 and $48.1 \%$, respectively.

In the current study, in vitro antibacterial activity and disease control efficacy of other essential oils against tomato bacterial wilt were evaluated. Clove oil showed potential to decrease tomato bacterial wilt, demonstrated by significant reduction of $R$. solanacearum growth in vitro and drastically alleviated disease severity of tomato plants without any phytotoxicity on tomato seedlings. Clove oil extracted from clove (Eugenia caryophyllata) is an essential oil. Eugenol was found to be a main ingredient of clove oil, revealed by the chemical composition analyses (Chaieb et al., 2007). Antifungal activity of clove oil is also well documented against Aspergillus niger, causing peanut crown rot (Kishore et al., 2007), Colletotrichum musae, causing banana anthracnose (Ranasinghe et al., 2002), and Monilinia fructicola, causing stone fruit brown rot (Lazar-Baker et al., 2011). In addition, biological activity has been intensively investigated in terms of antibacterial properties against human pathogenic microorganisms (Chaieb et al., 2007; Pinto et al., 2009). At least $0.005 \%$ of clove oil drench was demonstrated as an effective dose for controlling tomato bacterial wilt in pots. Field trials with clove oil for tomato production need to be applied in further studies. In addition, synergistic effect of clove oil and different chemical pesticides will be analyzed.

Taken together, tomato bacterial wilt was found to be controlled by 4 different pesticides and clove oil. These chemicals showed in vitro antibacterial activities against $R$. solanacearum, as well as disease protection efficacy to bacterial wilt. For the integrated management of tomato disease and insect pest, effect of various combinations of antibacterial pesticide and essential oils on disease protection should be considered in further studies. Additionally, a large number of eco-friendly essential oils and plant extracts remains to be screened for novel disease control agents to tomato bacterial wilt.

\section{Acknowledgements}

We appreciate Dr. Seon-Woo Lee, Department of Applied Biology, Dong-A University, South Korea for providing the $R$. solanacearum GMI1000 strain. This research was financially supported by the Research Center of Tomato Export (RCTE), the Institute of Planning and Evaluation for Technology of Food, Agriculture, Forestry and Fisheries (IPET), Republic of Korea, and also partially supported by Gyeongnam National University of Science and Technology Grant 2010 to Jeum Kyu Hong.

\section{References}

Adaskaveg, J. E. and Hine, R. B. 1985. Copper tolerance and zinc sensitivity of Mexican strains of Xanthomonas campestris pv. vesicatoria, causal agent of bacterial spot of pepper. Plant Dis. 69:993-996.

Adb-Alla, M. H. and Bashandy, S. R. 2008. Bacterial wilt and spot of tomato caused by Xanthomonas vesicatoria and Ralstonia solanacearum in Egypt. World J. Microbiol. Biotechnol. 24:291-292.

Ahmed, H. A. M., Abdel-Razik, A. A., Hassan, M. H. A. and Khaled, S. A. 2010. Management of charcoal rot of sesame by seed soaking in medicinal plant extracts and hot water. Plant Pathol. J. 26:372-379.

Aysan, Y. and Sahin, F. 2003. Occurrence of bacterial spot disease, caused by Xanthomonas axonopodis pv. vesicatoria, on pepper in the eastern Mediterranean region of Turkey. New Dis. Rep. 7:3.

Bajpai, V. K., Dung, N. T., Suh, H. J. and Kang, S. C. 2010. Antibacterial activity of essential oil and extracts of Cleistocalyx operculatus buds against the bacteria of Xanthomonas spp. $J$. Am. Oil Chem. Soc. 87:1341-1349.

Carmeille, A., Prior, P., Kodja, H., Chiroleu, F., Luisetti, J. and Besse, P. 2006. Evaluation of resistance to race 3, biovar 2 of Ralstonia solanacearum in tomato germplasm. J. Phytopathol. 154:398-402.

Chaieb, K., Hajlaoui, H., Zmantar, T., Kahla-Nakbi, A. B., 
Rouabhia, M., Mahdouani, K. and Bakhrouf, A. 2007. The chemical composition and biological activity of clove essential oil, Eugenia caryophyllata (Syzigium aromaticum L. Myrtaceae): A short review. Phytother. Res. 21:501-506.

Choi, N. H., Choi, G. J., Jang, K. S., Choi, Y. H., Lee, S. O., Choi, J. E. and Kim, J. C. 2008. Antifungal activity of the methanol extract of Myristica malabarica fruit rinds and the active ingredients malabaricones against phytopathogenic fungi. Plant Pathol. J. 24:317-321.

Colin, K. C. and McCarter, S. M. 1983. Effectiveness of selected chemicals in inhibiting Pseudomonas syringae pv. tomato in vitro and in controlling bacterial speck. Plant Dis. 67:639644.

Cuppels. D. A. and Elmhirst, J. 1999. Disease development and changes in the natural Pseudomonas syringae pv. tomato populations on filed tomato plants. Plant Dis. 83:759-764.

Enfinger, J. M., McCarter, S. M. and Jaworski, C. A. 1979. Evaluation of chemicals and application methods for control of bacterial wilt of tomato transplants. Phytopathology 69:637-640.

Frey, P., Prior, P., Marie, C., Kotoujansky, A., Trigalet-Demery, D. and Trigalet, A. (1994) Hrp- mutants of Pseudomonas solanacearum as potential biocontrol agents of tomato bacterial wilt. Appl. Environ. Microbiol. 60:3175-3181.

Graham, J. and Lloyd, A. B. 1979. Survival of the potato strain (race 3) of Pseudomonas solanacearum in the deeper soil layers. Aust. J. Agricult. Res. 30:489-496.

Guo, J. H., Qi, H. Y., Guo, Y. H., Ge, H. L., Gong, L. Y., Zhang, L. X. and Sun, P. H. 2004. Biocontrol of tomato wilt by plant growth-promoting rhizobacteria. Biol. Cont. 29:66-72.

Han, Y. K., Min, J. S., Park, J. H., Han, K. S., Kim, D. H., Lee, J. S. and Kim, H. H. 2009. Screening of tomato cultivars resistant to bacterial wilts. Res. Plant Dis. 15:198-201.

Hayward, A. C. 1991. Biology and epidemiology of bacterial wilt caused by Pseudomonas solanacearum. Annu. Rev. Phytopathol. 29:65-87.

Islam, T. M. D. and Toyota, K. .2004. Suppression of bacterial wilt of tomato by Ralstonia solanacearum by incorporation of composts in soil and possible mechanisms. Microbes Environ. 19:53-60.

Ishikawa, R., Fujimori, K. and Matsuura, K. 1996. Antibacterial activity of validamycin A against Pseudomonas solanacearum and its efficacy against tomato bacterial wilt. Annu. Phytopathol. Soc. Jpn. 62:478-482.

Isman, M. B. 2000. Plant essential oils for pest and disease management. Crop Protect. 19:603-608.

Jardine, D. J. and Stephens, C. T. 1987. Influence of timing of application and chemical on control of bacterial speck to tomato. Plant Dis. 71:405-408.

Ji, P., Momol, M. T., Olson, S. M., Pradhanang, P. M. and Jones, J. B. 2005. Evaluation of thymol as biofumigant for control of bacterial wilt of tomato under field conditions. Plant Dis. 89:497-500.

Jones, J. B., Stall, R. E. and Bouzar, H. 1998. Diversity among Xanthomonads pathogenic on pepper and tomato. Annu. Rev. Phytopathol. 36:41-58.

Kelman, A. 1954. The relationship of pathogenicity in Pseudomo- nas solanacearum to colony appearance on a tetrazolium medium. Phytopathology 44:693-695.

Kishore, G. K., Pande, S. and Harish, S. 2007. Evaluation of essential oils and their components for broad-spectrum antifungal activity and control of late leaf spot and crown rot diseases in peanut. Plant Dis. 91:375-379.

Lazar-Baker, E. E., Hetherington, S. D., Ku, V. V. and Newman, S. M. 2011. Evaluation of commercial essential oil samples on the growth of postharvest pathogen Monilinia fructicola (G. Winter) Honey. Lett. Appl. Microbiol. 52:227-232.

Lee, S. D. and Cho, Y. S. 1996. Copper resistance and race distribution of Xanthomonas campestris pv. vesicatoria on pepper in Korea. Kor. J. Plant Pathol. 12:150-155.

Liu, F., Wei, F., Wang, L., Liu, H., Zhu, X. and Liang, Y. 2010. Riboflavin activates defense responses in tobacco and induces resistance against Phytophthora parasitica and Ralstonia solanacearum. Physiol. Mol. Plant Pathol. 74:330-336.

Loreti, S., Fiori, M., de Simone, D., Falchi, G., Gallelli, A., Schiaffino, A. and Ena, S. 2008. Bacterial wilt, caused by Ralstonia solanacearum, on tomato in Italy. Plant Pathol. 57:368.

Louwes, F. J., Wilson, M., Campbell, H. L., Cuppels, D. A., Jones, J. B., Shemaker, P. B., Sahin, F. and Miller, S. A. 2001. Field control of bacterial spot and bacterial speck of tomato using a plant activator. Plant Dis. 85:481-488.

Marco, G. and Stall, R. E. 1983. Control of bacterial spot of pepper initiated by strains of Xanthomonas campestris pv. vesicatoria that differ in sensitivity to copper. Plant Dis. 67:779781.

Muthukumar, A., Eswaran, A., Nakkeeran, S. and Sangeetha, G. 2010. Efficacy of plant extracts and biocontrol agents against Pythium aphanidermatum inciting chilli damping-off. Crop Protect. 29:1483-1488.

Nakaho, K., Inoue, H., Takayama, T. and Miyagawa, H. 2004. Distribution and multiplication of Ralstonia solanacearum in tomato plants with resistance derived from different origins. $J$. Gen. Plant Pathol. 70:115-119.

Paret, M. L., Cabos, R., Kratky, B. A. and Alvarez, A. M. 2010. Effect of plant essential oils on Ralstonia solanacearum race 4 and bacterial wilt of edible ginger. Plant Dis. 94:521-527.

Park, E. J., Lee, S. D., Chung, E. J., Lee, M. H., Um, H. Y., Murugaiyan, S., Moon, B. J. and Lee, S. W. 2007a. Micro-Tom-A model plant system to study bacterial wilt by Ralstonia solanacearum. Plant Pathol. J. 23:239-244.

Park, K., Paul, D., Kim, Y. K., Nam, K. W., Lee, Y. K., Choi, H. W. and Lee, S. Y. 2007b. Induced systemic resistance by Bacillus vallismortis EXTN-1 suppressed bacterial wilt in tomato caused by Ralstonia solanacearum. Plant Pathol. J. 23:22-25.

Pinto, E., Vale-Siva, L., Cavaleiro, C. and Salgueiro, L. 2009. Antifungal activity of the clove essential oil from Syzygium aromaticum on Candida, Aspergillus and dermatophyte species. J. Med. Microbiol. 58:1454-1462.

Pradhanang, P. M., Ji, P., Momol, M. T., Olson, S. M., Mayfield, J. L. and Jones, J. B. 2005. Application of acibenzolar-S-methyl enhances host resistance in tomato against Ralstonia solanacearum. Plant Dis. 89:989-993. 
Pradhanang, P. M., Momol, M. T., Olson, S. M. and Jones, J. B. 2003. Effects of plant essential oils on Ralstonia solanacearum population density and bacterial wilt incidence in tomato. Plant Dis. 87:423-427.

Ranasinghe, L., Jayawardena, B. and Abeywickrama, K. 2002. Fungicidal activity of essential oils of Cinnamomum zeylanicum (L.) and Syzygium aromaticum (L.) Merr et L. M. Perry against crown rot and anthracnose pathogens isolated from banana. Lett. Appl. Microbiol. 35:208-211.

Ritchie, D. F. and Dittapongpitch, V. 1991. Copper and streptomycin-resistant strains and host differentiated races of Xanthomonas campestris pv. vesicatoria in North Carolina. Plant Dis. 75:733-736.

Robert, D. P., Denny, T. P. and Schell, M. A. 1988. Cloning of the egl gene of Pseudomonas solanacearum and analysis of its role in phytopathogenicity. J. Bacteriol. 170:1445-1451.

Romero, A. M., Kousik, C. S. and Ritchie, D. F. 2001. Resistance to bacterial spot in bell pepper induced by acibenzolar-Smethyl. Plant Dis. 85:189-194.

Saad, A. T. and Abul Hassam, H. M. 2000. Pathogenesis and control of bacterial speck, Pseudomonas syringae pv. tomato, on tomato. EPPO Bulletin 30:341-345.

Schaad, N. W., Jones, J. B. and Chun, W. 2001. Laboratory Guide for Identification of Plant Pathogenic Bacteria. 3rd ed. APS press, St Paul, USA.
Scherf, J. M., Milling, A. and Allen, C. 2010. Moderate temperature fluctuations rapidly reduce the viability of Ralstonia solanacearum race 3 , biovar 2, in infected geranium, tomato, and potato plants. Appl. Environ. Microbiol. 76:7061-7067.

Seo, S. T., Lee, J. S., Park, J. H., Han, K. S. and Jang, H. I. 2004. Inhibitory effect of garlic extracts on some plant pathogens. Res. Plant Dis. 10:349-252.

Soylu, E. M., Kurt, S. and Soylu, S. 2010. In vitro and in vivo antifungal activities of the essential oils of various plants against tomato grey mould disease agent Botrytis cinerea. Inter. J. Food Microbiol. 143:183-189.

Soylu, E. M., Soylu, S. and Kurt, S. 2006. Antimicrobial activities of the essential oils of various plants against tomato late blight disease agent Phytophthora infestans. Mycopathoogia 161: 119-128.

Suk, J. K., Ipper, N. S., Lee, S. H., Shrestha, A., Park, D. H., Cho, J. M., Hur, J. H., Kim, B. S. and Lim, C. K. 2006. Effects of a soil-born Paenibacillus spp. strain KPB3 on suppression of bacterial wilt disease caused by Ralstonia solanacearum. Kor. J. Pesticide Sci. 10:313-319.

van Elsas, J. D., Kastelein, P., van Bekkum, P., van der Wolf, J. M., de Vries, P. M. and van Overbeek, L. S. 2000. Survival of Ralstonia solanacearum biovar 2, the causative agent of potato brown rot, in field and microcosm soils in temperate climates. Phytopathology 90:1358-1366. 